\title{
Changes in plasma amino acid concentrations in man after ingestion of an amino acid mixture simulating casein, and a tryptic hydrolysate of casein
}

\author{
BY T. C. MARRS, JILL M. ADDISON, D. BURSTON AND \\ D. M. MATTHEWS \\ Department of Experimental Chemical Pathology, \\ Vincent Square Laboratories of Westminster Hospital, \\ ${ }_{24}$ Vauxhall Bridge Road, London $S W_{1} V{ }_{2} R H$
}

(Received 3 December 1974-Accepted 10 February 1975)

\begin{abstract}
1. Plasma amino acid levels have been estimated at $0,15,30$ and $45 \mathrm{~min}$ after ingestion of doses of ( $\mathrm{x}$ ) an amino acid mixture simulating casein and (2) a tryptic hydrolysate of casein consisting mainly of oligopeptides. Both doses contained the same amount of nitrogen.

2. After ingestion of both preparations, there was a prompt increase in plasma amino acid levels, followed by a decrease. No such change occurred in fasting subjects. There were no significant differences between increments in plasma amino acid levels after ingestion of the amino acid mixture and the corresponding increments after ingestion of the tryptic hydrolysate. 3. Correlations were found between the areas under the curves for individual amino acid concentrations, after ingestion of the two preparations, and the amino acid composition of casein. The results do not suggest that increases in plasma amino acid levels following small doses of protein digestion products are the result of circadian changes, or that such increases are 'swamped' by absorption of amino acids from endogenous protein in the lumen of the small intestine.
\end{abstract}

It has been reported that two important factors influencing plasma amino acid levels are the time of day and protein ingestion. A considerable amount is known about circadian variation in amino acid levels for peripheral plasma (Feigin, Klainer \& Beisel, I967; Wurtman, Chou \& Rose, r967; Scriver $\&$ Rosenberg, I973), and many workers have found that there is an increase in the amino acid levels of portal plasma during protein absorption (e.g. Dent \& Schilling, 1949; Dawson, Holdsworth \& Porter, I964; Elwyn, Parikh \& Shoemaker, ı 968 ; for further references see Matthews, 1975), but reports of the effect of protein ingestion on the levels of individual amino acids in the peripheral plasma are conflicting. In man, Stein \& Moore (1954), Frame (1958), Richmond \& Girdwood (1962), Floyd, Fajans, Conn, Knopf \& Rull (1966), Yearick \& Nadeau (1967), Nasset \& Ju (1969) and Adibi \& Mercer (I973) described an increase after ingestion of protein, but Rouser, Jelinek, Samuels \& Kinugasa (1962) reported that there was little or no change. Ganapathy $\&$ Nasset (1962) reported that for the dog, plasma amino acid levels might either increase or decrease after a protein meal, and Peraino \& Harper ( 1963 ) found that, for the rat, force-feeding with zein had little effect on the amino acid concentrations for portal and peripheral plasma, although these did increase after ingestion of casein and acid-hydrolysates of both proteins. Longenecker \& Hause (1959) reported that in some instances amino acid concentrations in the peripheral plasma of the dog decreased after ingestion of a meal containing $32 \mathrm{~g}$ casein or gelatin. Feigin et al. (1967) suggested that increases in plasma 
Table 1. Composition of amino acid mixture simulating casein used in studies of changes in plasma amino acid concentrations in man

(Values are calculated from the data of Ling, Kon \& Porter (196I) and are expressed as molar ratios relative to histidine)

Amino acid

$\begin{array}{ll}\text { Histidine } & \mathbf{I} \cdot 00 \\ \text { Lysine } & \mathbf{2} \cdot 88 \\ \text { Arginine } & \mathrm{I} \cdot \mathbf{2 3} \\ \text { Glutamic acid* } & 8 \cdot 28 \\ \text { Proline } & 5 \cdot 50 \\ \text { Glycine } & \mathrm{I} \cdot 43 \\ \text { Alanine } & \mathrm{I} \cdot 8 \mathrm{I} \\ \text { Serine } & 3 \cdot 07 \\ \text { Threonine } & \mathrm{I} \cdot 90\end{array}$

$\begin{array}{ll}\text { Amino acid } & \\ \text { Valine } & 3 \cdot 26 \\ \text { Methionine } & \mathrm{I} \cdot 12 \\ \text { Isoleucine } & 2 \cdot 64 \\ \text { Leucine } & 4 \cdot 00 \\ \text { Tyrosine } & \mathrm{I} \cdot 3^{8} \\ \text { Phenylalanine } & \mathrm{I} \cdot 8 \mathrm{I} \\ \text { Aspartic acid* } & 2 \cdot 5 \mathrm{I} \\ \text { Cystine } & 0 \cdot 10 \\ \text { Tryptophan } & 0 \cdot 3^{8}\end{array}$

* In casein, approximately half the glutamic acid of the above mixture is glutamine, and approximately half the aspartic acid is asparagine (Mercier, Grosclaude \& Ribadeau-Dumas, 1972). In relating the composition of the materials given to the increments in plasma amino acid levels (see Results), half the above molar value for glutamic acid was taken when considering the tryptic hydrolysate of casein.

amino acid levels following a protein meal (Frame, 1958) might be related to circadian changes rather than a consequence of the meal. If the quantity of endogenous protein absorbed from the small. intestine is as large as has been suggested (Nasset, I964, 1965) it might be expected that ingestion of a small amount of protein or the digestion products of protein would have relatively little effect on plasma amino acid levels.

It has recently been shown by jejunal perfusion in man that there are definite differences in the patterns of absorption of individual amino acids from an amino acid mixture simulating a protein, and from partial hydrolysates of that protein more closely resembling the normal products of intraluminal protein digestion (Silk, Marrs, Addison, Burston, Clark \& Matthews, I973; Silk, Clark, Marrs, Addison, Burston, Matthews \& Clegg, 1975). These differences are the result of mucosal peptide uptake followed by intracellular hydrolysis, leading to more rapid absorption from the enzymic hydrolysates of several amino acids which are relatively slowly absorbed from the amino acid mixture: in the instance of a tryptic hydrolysate, these are lysine, glutamic acid, aspartic acid, alanine, phenylalanine and histidine (Silk et al. 1973). The present study had two objectives: (I) to find out whether there was any significant change in the amino acid concentrations for peripheral plasma after ingestion of a small dose of a partial enzymic hydrolysate of a protein, and after an amino acid mixture of similar composition, or whether changes might be masked or simulated by circadian variation; (2) to determine whether there were differences between the increments of individual amino acids after ingestion of the enzymic hydrolysate and the amino acid mixture.

\section{METHODS AND MATERIALS}

Six normal adult human volunteers (four men and two women, aged between 20 and 30 years) ingested at 09.30 hours on different days, in random order and after an overnight fast: ( I) Io g amino acid mixture simulating casein; (2) 9.4 g tryptic hydrolysate of casein, which contained the same amount of nitrogen as the dose of the amino acid 
Table 2. Resting values and increments in plasma amino acid concentrations $(\mu m o l / l)$ for man at various intervals after ingestion of equivalent doses of a tryptic hydrolysate of casein or an amino acid mixture simulating casein $\dagger$

(Mean values with their standard errors for six subjects (four men and two women))

\begin{tabular}{|c|c|c|c|c|c|c|c|c|}
\hline \multirow[b]{3}{*}{ Amino acid } & \multirow[b]{3}{*}{ Material ingested } & \multirow{3}{*}{$\begin{array}{l}\text { Mean } \\
\text { resting } \\
\text { values } \\
\text { (o min) }\end{array}$} & \multicolumn{6}{|c|}{ Increment at: } \\
\hline & & & \multicolumn{2}{|c|}{ I5 $\mathrm{min}$} & \multicolumn{2}{|c|}{$30 \mathrm{~min}$} & \multicolumn{2}{|c|}{$45 \mathrm{~min}$} \\
\hline & & & Mean & SE & Mean & $\mathrm{SE}$ & Mean & SE \\
\hline Histidine & $\begin{array}{l}\text { None } \\
\text { Tryptic hydrolysate } \\
\text { Amino acid mixture }\end{array}$ & $\begin{array}{l}92 \\
96 \\
96\end{array}$ & $\begin{array}{r}-1 \\
26 \\
14\end{array}$ & $\begin{array}{l}2 \\
17^{*} \\
4^{* * *}\end{array}$ & $\begin{array}{r}-3 \\
38 \\
35\end{array}$ & $\begin{array}{l}\mathrm{x} \\
4^{* * * *} \\
9^{* * *}\end{array}$ & $\begin{array}{r}-1 \\
19 \\
20\end{array}$ & $\begin{array}{l}4 \\
6 * * * \\
6^{* * * *}\end{array}$ \\
\hline Glycine & $\begin{array}{l}\text { None } \\
\text { Tryptic hydrolysate } \\
\text { Amino acid mixture }\end{array}$ & $\begin{array}{l}209 \\
239 \\
240\end{array}$ & $\begin{array}{r}-5 \\
15 \\
24\end{array}$ & $\begin{array}{l}\text { I3 } \\
\text { I2 } \\
7^{*}\end{array}$ & $\begin{array}{r}5 \\
48 \\
41\end{array}$ & $\begin{array}{l}10 \\
8 * * * \\
7 * * *\end{array}$ & $\begin{array}{r}\mathbf{I} \\
8 \\
2 \mathrm{I}\end{array}$ & $\begin{array}{c}10 \\
5 \\
16^{*}\end{array}$ \\
\hline Alanine & $\begin{array}{l}\text { None } \\
\text { Tryptic hydrolysate } \\
\text { Amino acid mixture }\end{array}$ & $\begin{array}{l}272 \\
314 \\
299\end{array}$ & $\begin{array}{r}16 \\
6 \\
50\end{array}$ & $\begin{array}{r}8 \\
27 \\
22\end{array}$ & $\begin{array}{r}9 \\
106 \\
157\end{array}$ & $\begin{array}{l}14 \\
28 * * \\
38^{* * *}\end{array}$ & $\begin{array}{r}-2 \\
67 \\
121\end{array}$ & $\begin{array}{l}15 \\
4 I^{*} \\
35^{* * *}\end{array}$ \\
\hline Valine & $\begin{array}{l}\text { None } \\
\text { Tryptic hydrolysate } \\
\text { Amino acid mixture }\end{array}$ & $\begin{array}{l}215 \\
207 \\
228\end{array}$ & $\begin{array}{r}2 \\
83 \\
105\end{array}$ & $\begin{array}{l}4 \\
15^{* * * *} \\
22^{* * * *}\end{array}$ & $\begin{array}{r}I_{3} \\
149 \\
12 I\end{array}$ & $\begin{array}{l}7 \\
30^{* * * *} \\
22^{* * * *}\end{array}$ & $\begin{array}{r}-4 \\
96 \\
94\end{array}$ & $\begin{array}{l}7 \\
15^{* * * *} \\
20^{* * * *}\end{array}$ \\
\hline Leucine & $\begin{array}{l}\text { None } \\
\text { Tryptic hydrolysate } \\
\text { Amino acid mixture }\end{array}$ & $\begin{array}{l}\text { I } 13 \\
\text { I } 2 \text { I } \\
142\end{array}$ & $\begin{array}{r}-3 \\
99 \\
93\end{array}$ & $\begin{array}{l}5 \\
18 * * * \\
15^{* * * *}\end{array}$ & $\begin{array}{r}9 \\
130 \\
128\end{array}$ & $\begin{array}{l}6 \\
17^{* * * *} \\
12^{* * * *}\end{array}$ & $\begin{array}{r}-5 \\
77 \\
53\end{array}$ & $\begin{array}{l}4 \\
18^{* * * *} \\
18^{* * * *}\end{array}$ \\
\hline Isoleucine & $\begin{array}{l}\text { None } \\
\text { Tryptic hydrolysate } \\
\text { Amino acid mixture }\end{array}$ & $\begin{array}{l}59 \\
6 \mathrm{I} \\
68\end{array}$ & $\begin{array}{r}\mathbf{I} \\
49 \\
83\end{array}$ & $\begin{array}{l}2 \\
9^{* * * *} \\
16 * * *\end{array}$ & $\begin{array}{r}3 \\
80 \\
83\end{array}$ & $\begin{array}{l}4 \\
9^{* * * *} \\
7^{* * * *}\end{array}$ & $\begin{array}{r}-2 \\
39 \\
41\end{array}$ & $\begin{array}{l}4 \\
8 * * * \\
7 * * *\end{array}$ \\
\hline Methionine & $\begin{array}{l}\text { None } \\
\text { Tryptic hydrolysate } \\
\text { Amino acid mixture }\end{array}$ & $\begin{array}{l}28 \\
33 \\
38\end{array}$ & $\begin{array}{r}-4 \\
23 \\
36\end{array}$ & $\begin{array}{l}2 \\
5^{* * * *} \\
\mathrm{II}^{* * * *}\end{array}$ & $\begin{array}{r}-2 \\
26 \\
25\end{array}$ & $\begin{array}{l}2 \\
6 * * * * \\
4^{* * * *}\end{array}$ & $\begin{array}{r}-2 \\
13 \\
12\end{array}$ & $\begin{array}{l}3 \\
4 * * * \\
6 *\end{array}$ \\
\hline Tyrosine & $\begin{array}{l}\text { None } \\
\text { Tryptic hydrolysate } \\
\text { Amino acid mixture }\end{array}$ & $\begin{array}{l}47 \\
55 \\
57\end{array}$ & $\begin{array}{r}0 \\
31 \\
26\end{array}$ & $\begin{array}{l}1 \\
6 * * * * \\
5 * * *\end{array}$ & $\begin{array}{r}3 \\
52 \\
3 I\end{array}$ & $\begin{array}{l}4 \\
9 * * * * \\
4^{* * * *}\end{array}$ & $\begin{array}{r}5 \\
37 \\
26\end{array}$ & $\begin{array}{l}5 \\
6 * * * \\
4^{* * * *}\end{array}$ \\
\hline Phenylalanine & $\begin{array}{l}\text { None } \\
\text { Tryptic hydrolysate } \\
\text { Amino acid mixture }\end{array}$ & $\begin{array}{l}46 \\
53 \\
58\end{array}$ & $\begin{array}{r}-I \\
24 \\
19\end{array}$ & $\begin{array}{l}2 \\
4^{* * * *} \\
4^{* * *}\end{array}$ & $\begin{array}{r}2 \\
31 \\
23\end{array}$ & $\begin{array}{l}3 \\
4^{* * * *} \\
3^{* * *}\end{array}$ & $\begin{array}{r}-2 \\
15 \\
8\end{array}$ & $\begin{array}{l}\mathbf{I} \\
3^{* * * *} \\
3^{* * *}\end{array}$ \\
\hline Proline & $\begin{array}{l}\text { None } \\
\text { Tryptic hydrolysate } \\
\text { Amino acid mixture }\end{array}$ & $\begin{array}{l}177 \\
193 \\
178\end{array}$ & $\begin{array}{r}-6 \\
59 \\
\text { IOI }\end{array}$ & $\begin{array}{l}4 \\
29^{* *} \\
18 * * *\end{array}$ & $\begin{array}{l}-2 \\
132 \\
152\end{array}$ & $\begin{array}{l}14 \\
33^{* * *} \\
28 * * *\end{array}$ & $\begin{array}{r}3 \\
84 \\
80\end{array}$ & $\begin{array}{l}16 \\
23 * * * \\
28 * * *\end{array}$ \\
\hline Lysine & $\begin{array}{l}\text { None } \\
\text { Tryptic hydrolysate } \\
\text { Amino acid mixture }\end{array}$ & $\begin{array}{l}201 \\
192 \\
214\end{array}$ & $\begin{array}{r}9 \\
109 \\
152\end{array}$ & $\begin{array}{l}\text { ro } \\
\text { I5**** } \\
15 * * *\end{array}$ & $\begin{array}{r}23 \\
171 \\
193\end{array}$ & $\begin{array}{l}\text { 10 } \\
41^{* * * *} \\
53^{* * * *}\end{array}$ & $\begin{array}{l}17 \\
65 \\
76\end{array}$ & $\begin{array}{l}9 \\
9^{* * * * *} \\
28^{*}\end{array}$ \\
\hline Arginine & $\begin{array}{l}\text { None } \\
\text { Tryptic hydrolysate } \\
\text { Amino acid mixture }\end{array}$ & $\begin{array}{l}110 \\
106 \\
105\end{array}$ & $\begin{array}{r}-I \\
28 \\
43\end{array}$ & $\begin{array}{l}4 \\
16 * * \\
8 * * *\end{array}$ & $\begin{array}{r}-9 \\
44 \\
68\end{array}$ & $\begin{array}{l}6 \\
\text { I9** } \\
\text { I } 8^{* * *}\end{array}$ & $\begin{array}{r}-\mathrm{II} \\
17 \\
29\end{array}$ & $\begin{array}{l}\text { I0 } \\
8 * \\
\text { II*** }\end{array}$ \\
\hline Glutamic acid & $\begin{array}{l}\text { None } \\
\text { Tryptic hydrolysate } \\
\text { Amino acid mixture }\end{array}$ & $\begin{array}{l}\text { I 30 } \\
\text { I 35 } \\
\text { I32 }\end{array}$ & $\begin{array}{l}12 \\
25 \\
30\end{array}$ & $\begin{array}{r}5 \\
9 \\
\mathrm{I} 2\end{array}$ & $\begin{array}{l}13 \\
43 \\
23\end{array}$ & $\begin{array}{l}6 \\
17^{*} \\
\text { I } 3\end{array}$ & $\begin{array}{r}-1 \\
4 \\
1\end{array}$ & $\begin{array}{l}14 \\
23 \\
14\end{array}$ \\
\hline
\end{tabular}

Significance of difference between increment in plasma level for subjects after ingestion of test materials and that for fasting subjects at the same time: ${ }^{*}<0.2, * * P<0.1, * * * P<0.05$. The paired $t$ test was used.

$\dagger$ For details of composition, see Table $\mathbf{r}$. 


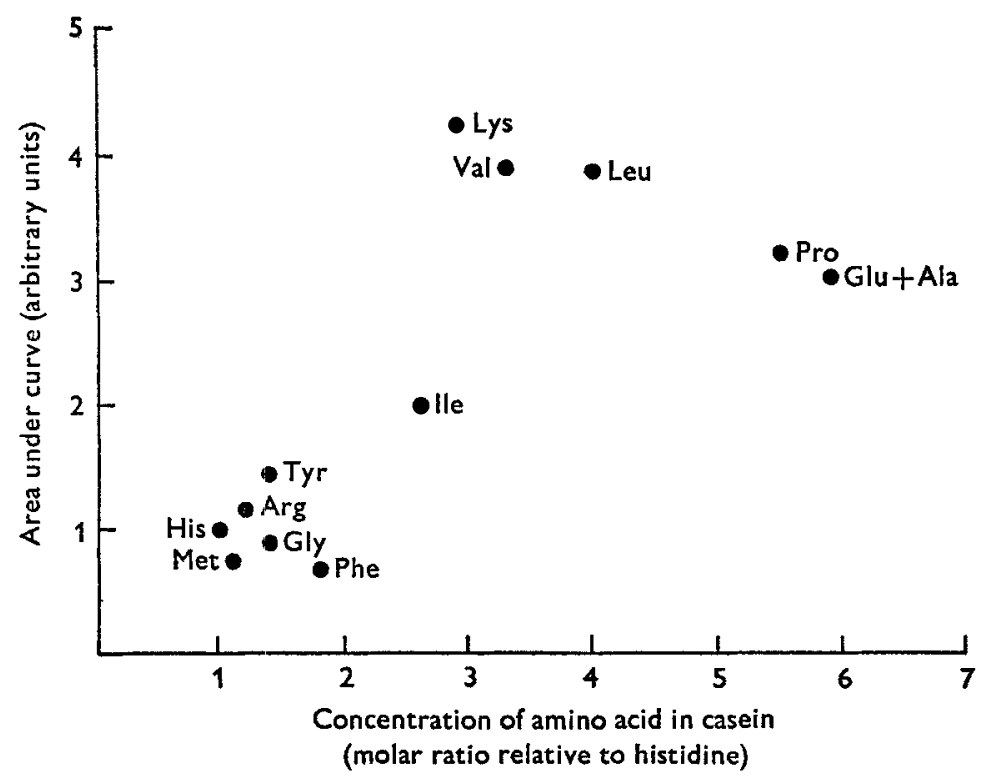

Fig. I. Correlation between areas under curves for individual plasma amino acid levels following ingestion by man of a tryptic hydrolysate of casein, and the amino acid composition of casein (for details of composition, see Table r). His, histidine; Met, methionine; Arg, arginine; Tyr, tyrosine; Gly, glycine; Phe, phenylalanine; Ile, isoleucine; Lys, lysine; Val, valine; Leu, leucine; Pro, proline; Glu + Ala, glutamic acid + alanine.

mixture; each dose was given in $180 \mathrm{ml}$ water. The composition of the amino acid mixture was based on that of casein, as given by Ling, Kon \& Porter (I96r) (Table I). The tryptic hydrolysate of casein was made as previously described, by digestion with crude trypsin, and contained about two-thirds small peptides of mean chain length two to three amino acid residues and one-third free amino acids (Crampton, Gangolli, Simson \& Matthews, I971).

Venous blood samples were taken immediately before ingestion of the doses and I 5, 30 and $45 \mathrm{~min}$ afterwards. After deproteinization using dilute salicylsulphonic acid $(6 \circ \mathrm{g} / \mathrm{l})(\mathrm{I}: \mathrm{I}, \mathrm{v} / \mathrm{v})$, plasma amino acid levels were determined by ion-exchange chromatography using an automatic-loading amino acid analyser (The Locarte Company, 8 Wendell Road, London Wr2 9 RT). Threonine, serine, tryptophan, cystine, glutamine and asparagine were not estimated, and levels of aspartic acid were too low for estimation in the sensitivity range used. The behaviour of the plasma amino acid levels for the same subjects when fasting was studied by measuring plasma amino acid levels at the same time intervals, at the same time of day on another occasion.

\section{RESULTS}

There was very little change in the plasma amino acid levels of fasting subjects over the relatively short period of $45 \mathrm{~min}$. All amino acids estimated showed increases in plasma levels after ingestion of the tryptic hydrolysate and the amino acid mixture (Table 2), although for glutamic acid they were not statistically significant, and for 
alanine and arginine increases after ingestion of the tryptic hydrolysate were not significant $(P>0.05)$. In many instances increases occurred as early as 15 min after ingestion. At $45 \mathrm{~min}$, levels were decreasing from the peak values. The largest increases were in lysine, proline, alanine, valine and leucine, all at $30 \mathrm{~min}$ after ingestion. Differences between increments in plasma amino acid levels after ingestion of the amino acid mixture and the corresponding increments after ingestion of the tryptic hydrolysate were not statistically significant, but possibly occurred with phenylalanine (mean increment 3I $\mu \mathrm{mol} / 1$ after the tryptic hydrolysate, $23 \mu \mathrm{mol} / 1$ after the amino acid mixture $(P<0 \cdot 1)$ at $30 \mathrm{~min})$. There were no significant differences in the areas under the curves for any amino acid following ingestion of the tryptic hydrolysate and ingestion of the amino acid mixture.

To determine whether there was any relationship between the amino acid composition of the materials fed and the increments in the levels of individual plasma amino acids, the areas under the curves for the increments for each plasma amino acid were expressed in arbitrary units and plotted $v$. the amino acid composition of the materials expressed on a molar basis relative to histidine (Fig. I). Since glutamic acid is transaminated by the intestinal mucosa, entering the blood mainly as alanine (see Discussion) the sum of glutamic acid + alanine was used for the plots, and treated as one amino acid. A significant correlation was found for both the amino acid mixture and the enzymic hydrolysate: amino acid mixture: $r 0.67, P<0.02$; tryptic hydrolysate: $r 0.72, P<0.01$.

\section{DISCUSSION}

The results show that following ingestion of small doses of a tryptic hydrolysate of casein or an amino acid mixture simulating casein there was a prompt increase in the plasma levels of most amino acids measured, followed by a decrease towards fasting levels. This increase was not the result of circadian changes, nor was it so 'swamped' by amino acids absorbed from endogenous proteins entering the small intestine (Nasset, 1964, 1965) that it was almost imperceptible.

The absence of a significant increase in glutamic acid levels after the doses of the amino acid mixture and tryptic hydrolysate, although there was a substantial proportion of this amino acid in the two preparations, is probably largely due to transamination by the intestinal mucosa, which results in absorption of much glutamic acid as alanine (Wiseman, 1974). Previous workers have noted the absence of an increase in plasma glutamic acid concentrations after the administration of casein or a casein hydrolysate (Dent \& Schilling, 1949; Peraino \& Harper, 1963). Another factor possibly contributing is utilization of glutamic acid in the synthesis of glutathione by the intestinal mucosa (Elwyn et al. I968).

The changes in the peripheral plasma in the present study did not reflect the marked differences between the pattern of absorption for individual amino acids from a tryptic hydrolysate of casein and from an equivalent amino acid mixture found in jejunal perfusion experiments in which disappearance from the lumen was measured (Silk et al. x973). It is unlikely that this can be entirely attributed to a possible difference in the rate of gastric emptying after administration of the tryptic hydrolysate and after 
the amino acid mixture. The effect of such a difference would be to produce a uniform increase or decrease in the rates of absorption of all amino acids from one preparation relative to the other. Thus differences in the patterns of absorption for individual amino acids from the two preparations should still be apparent. Possibly the actions of intraluminal proteases and peptidases are more intense under the present conditions than in the jejunal perfusion experiments, so that the peptides of the tryptic hydrolysate are largely hydrolysed to amino acids before mucosal uptake: the results of recent perfusion experiments (Silk, Clark, Marrs, Addison, Burston, Matthews \& Clegg, unpublished results) suggest that more definite differences between the pattern of absorption following the tryptic hydrolysate and that following the amino acid mixture might have been found at higher dose levels.

It is widely believed that the pattern of appearance for amino acids in peripheral plasma is unrelated to the amino acid composition of the material ingested (Frame, 1958; Yearick \& Nadeau, 1967 ), because of the influence of tissue uptake and release of amino acids, especially by the liver (Miller, 1962 ) and because, according to Nasset (1965) ingested protein is mixed with several times its mass of endogenous protein so that an amino acid mixture of relatively constant composition is delivered to the portal blood. In view of this it is interesting that in the present work correlations were found between the amino acid composition of the materials ingested and the extent of the increases in the concentrations of amino acids in the plasma. Adibi \& Mercer (1973) previously reported a similar correlation after ingestion of $50 \mathrm{~g}$ bovine serum albumin in man. Further studies may explain the reason for the conflicting findings.

The authors are grateful to Mr J. Milner of Milner Scientific and Medical Research Company Limited, 4I North John Street, Liverpool L2 6SE for preparation of the tryptic hydrolysate and amino acid mixture. This work was supported by a grant to D.M.M. from the Medical Research Council.

\section{REFERENCES}

Adibi, S. A. \& Mercer, D. W. (1973). F. clin. Invest. 52, 1586.

Crampton, R. F., Gangolli, S. D., Simson, P. \& Matthews, D. M. (197r). Clin. Sci. 41, 409.

Dawson, R., Holdsworth, E. S. \& Porter, J. W. G. (1964). In The Role of the Gastro-intestinal Tract in Protein Metabolism, p. 293 [H. N. Munro, editor]. Oxford: Blackwell Scientific Publications.

Dent, C. E. \& Schilling, J. A. (1 949). Biochem. F. 44, 318.

Elwyn, D. H., Parikh, H. C. \& Shoemaker, W. C. (rg68). Am. J. Physiol. 215, r26o.

Feigin, R. D., Klainer, A. S. \& Beisel, W. R. (rg67). Nature, Lond. 215, 5 I 2.

Floyd, J. C., Fajans, S. S., Conn, J. W., Knopf, R. F. \& Rull, J. (1966). F. clin. Invest. 45, I479.

Frame, E. G. (1958). F. clin. Invest. 37, 1710.

Ganapathy, S. N. \& Nasset, E. S. (1962). F. Nutr. 78, 241.

Ling, E. R., Kon, S. K. \& Porter, J. W. G. (I96I). In The Mammary Gland and its Secretion, vol. 2, p. I 95 [S. K. Kon and A. TT. Cowie, editors]. New York and London: Academic Press.

Longenecker, J. B. \& Hause, N. L. (1959). Archs Biochem. Biophys. 84, 46.

Matthews, D. M. (1975). In Peptide Transport in Protein Nutrition, p. 6I [D. M. Matthews and J. W. Payne, editors]. Amsterdam: Associated Scientific Publishers.

Mercier, J. C., Grosclaude, F. \& Ribadeau-Dumas, B. (1972). Milchwissenschaft 27, 402.

Miller, L. L. (r962). In Amino Acid Pools, p. 708 [J. T. Holden, editor]. Amsterdam: Associated Scientific Publishers.

Nasset, E. S. (1964). Am F. dig. Dis. 9, 175.

Nasset, E. S. (1965). Fedn Proc. Fedn Am. Socs exp. Biol. 24, 953.

Nasset, E. S. \& Ju, J. S. (1969). Proc. Soc. exp. Biol. Med. 132, 1077. 
Peraino, C. \& Harper, A. E. (1963). Y. Nutr. 80, 270.

Richmond, J. \& Girdwood, R. H. (1962). Clin. Sci. 22, 301.

Rouser, G., Jelinek, B., Samuels, A. J. \& Kinugasa, K. (ig62). In Amino Acid Pools, p. 350 [J. T. Holden, editor]. Amsterdam: Associated Scientific Publishers.

Scriver, C. R. \& Rosenberg, L. E. (1973). Amino Acid Metabolism and its Disorders, p. 39. Philadelphia and London: W. B. Saunders Co.

Silk, D. B. A., Clark, M. L., Marrs, T. C., Addison, J. M., Burston, D., Matthews, D. M. \& Clegg, K. M. (1975). Br. F. Nutr. 33, 95 .

Silk, D. B. A., Marrs, T. C., Addison, J. M., Burston, D., Clark, M. L. \& Matthews, D. M. (r973). Clin. Sci. mol. Med. 45, 7 I 5.

Stein, W. H. \& Moore, S. (1954). 7. biol. Chem. 211 , 915.

Wiseman, G. (1974). In Biomembranes, vol. 4A, p. 363 [D. H. Smyth, editor]. London and New York: Plenum Press.

Wurtman, R. J., Chou, C. \& Rose, C. M. (1967). Science, N. Y. 158, 660.

Yearick, E. S. \& Nadeau, R. G. (1967). Am. F. clin. Nutr. 20, 338. 